\title{
Regional Trade Blocs and the GATT
}

\author{
John H. Jackson
}

\section{INTRODUCTION ${ }^{1}$}

1

NTERNATIONAL economic interdependence is now commonly recognised as a growing phenomenon. Economic events, whether caused by certain government decisions or otherwise, have impacts on neighbouring nations, as well as on those on the other side of the globe, and these impacts often occur very swiftly and profoundly. This is leading to frustration on the part of national political leaders, who find it increasingly difficult to take action within their countries which can reasonably fulfill goals of constituencies. Certain kinds of tensions arise between nations because of this phenomenon, and those tensions can threaten to disrupt economic or even political relationships in a way that can be damaging to goals of increasing world welfare, or maintenance of the peace.

Since the early days after World War II, statesmen and political leaders have expressed the goal of developing an international economic institutional framework, which would prevent or inhibit some of the damaging economic characteristics which affected the world in the earlier part of this century. The Bretton Woods System, broadly defined to include not only the IMF and the World Bank, but also the GATT trading system (after the failure of an International Trade Organisation Charter to come into effect), was one result of these policy goals. Subsequently, there developed major initiatives in various parts of the world towards regional trading blocs. Thus, there is now increasing attention given to the question of whether the world is better served with an overall multilateral system (such as a GATT/MTO system), ${ }^{2}$ or by various trading blocs. There seems to be some trend towards a world with three major blocs: Europe, Western Hemisphere and

JOHN H. JACKSON is Hessel E. Yntema Professor of Law at the University of Michigan, School of Law, Ann Arbor, Michigan, USA.

1 This article is partially adapted from a paper delivered at a conference in Buenos Aires, Argentina, July 1992. Comments from an anonymous referee are gratefully acknowledged.

${ }^{2}$ See Draft Final Act Embodying the Results of the Uruguay Round of Multilateral Trade Negotiations ('The Dunkel Draft'), GATT Doc. MTN.TNC/W/FA (20 December 1991). MTO = Multilateral Trade Organisation as proposed in a Draft Charter in the Dunkel Draft. 
Pacific region. On the other hand, there is considerable concern that the development of such blocs could create the characteristics of tensions and conflict. Thus, the relationship of a broad multilateral system to the various actual or potential trade blocs is under discussion. ${ }^{3}$ That relationship is the focus of this article.

Although the subject of this article deals primarily with economic matters, it must be recognised that there are various relationships to non-economic policies. Of course, there are links between the rules of trading blocs and a multilateral trading system, with such subjects as investment, monetary policy, environmental quality, etc. But there are also clearly links to subjects such as human rights, democratisation, demilitarisation and other political relationships, such as arms control. ${ }^{4}$ These linkages cannot be totally ignored and indeed it has sometimes been said that economic integration, such as that experienced in some of the trading blocs (especially Europe), simply will not work satisfactorily even to achieve economic goals, unless there is a strong political goal motivating the economic integration. In Europe, this strong political goal was seen from the inception of the European economic integration institutions (the Coal and Steel Community 1952 and the Treaty of Rome of 1957) as relating to the overwhelming objective of preventing World War III, and particularly preventing conflict between France and Germany (see Fontaine, 1987; D'Oppuers, 1987; and Jackson, 1992). In other regional blocs, political goals may not be so obvious, but they surely exist in the background. ${ }^{5}$ Part of the attention we give to the issues of the relationship of a multilateral trading system with that of trade blocs must take cognisance of non-economic goals.

In this article, I will discuss some of these issues in five further sections. Section 2 discusses the policies of the GATT/MTO trading system regarding regional trading blocs and the reasons for GATT exceptions to its broader policy of most-favourednation. Section 3 discusses some of the specifics of the GATT rules and the experience under them. Most detail, however, will be left to other referenced works. Section 4 considers issues that go beyond the original notions of policy expressed in the GATT, and indeed relate to a series of new trade and economic issues which are faced by the multilateral trade system as well as trading blocs. Likewise, we

\footnotetext{
${ }^{3}$ Address by Mr Arthur Dunkel, Director-General of GATT, to the Conference of the International Herald Tribune in Association with the International Chamber of Commerce, Paris, France, 2 April 1992, reprinted in GATT Doc. GATT/1540 (3 April 1992).

${ }^{4}$ See Smith (1992); Address by President Bush to the Forum of the Americas, Washington, DC, 23 April 1992, excerpts reprinted in US State Dept., Dispatch, 4 May 1992, at p. 333; Round Table Discussion, 'North America Free Trade Agreement: In Whose Best Interest?', Northwestern University School of Law, 17 October 1991, reprinted in Northwestern Journal of International Law and Business, Vol. 12, at pp. 541-43, 549-50, 568-70 (1992) (hereinafter 'Round Table Discussion'); Morici (1992) Hurrell (1992) and Jackson (1992).

${ }^{5}$ Statement of Rober B. Zoellick, Counsellor of the State Department, before the Senate Foreign Relations Committee, 11 April 1991, reprinted in US State Dept., Dispatch, 15 April 1991, at pp. 254-56.
} 
will look briefly at some of the deepening questions of linkages to non-economic goals and effects on matters such as cultural/political change.

Section 5 addresses particularly the Western Hemisphere and its possibilities with respect to regional integration and, finally, Section 6 discusses ways of reconciling the apparent tension between multilateral supervision of international economic actions and supervision within various trading blocs, drawing some conclusions and possibilities for future action.

\section{POLICIES}

The starting point for considering policies relating to regional trade blocs and the multilateral trade system is the most-favoured-nation ('MFN') clause, particularly that in Article I of GATT. The policies regarding MFN are generally well known, but are reasonably complex. Particularly in a world where the multilateral system embraces MFN but includes more than 100 countries, there are a number of problems engendered by an MFN. These problems are characterised as 'the free rider', or 'lowest common denominator' problems (Jackson, 1983 and 1989). Nevertheless, the basic idea that trade in the world should proceed with the least possible amount of discrimination among countries, so as to facilitate trade, reduce the transaction costs (such as determining origin of goods) and reduce tensions, remains one of the central pillars of the multilateral system.

Even at the outset of this system, however, it was recognised that there would be exceptions to MFN. The most significant exception is that expressed in Article XXIV of GATT, which allows the creation of certain kinds of preferential trading blocs if certain criteria are met. The basic policy goal was to allow preferential trading arrangements if they constituted a genuine attempt to develop free trade within the bloc. This notion is expressed by the 'substantially all' criterion, discussed in Section 3 below. Often, it has been stated that the goal of the exception of Article XXIV was 'trade creating' rather than 'trade diverting' (Jackson, 1969, p. 580 and 1989, p. 141; GATT, 1991, p. S2; and Bradsher, 1992).

With the development of preferential agreements for and among developing countries in the GATT, as represented in the GSP programmes and later in the Tokyo Round 'understanding' (often called the 'enabling clause'; see GATT, 1980, p. 203), a new policy was introduced about which there is some ambivalence. This policy expressed the desire to allow preferential systems which benefit developing countries, as part of a general trend at that time within the GATT to give special favours to developing countries. As some developing countries have become 'newly industrialising', there has developed a trend to encourage, or pressure such countries, into a fuller acceptance of the rules of the GATT trading system. This has been strongly manifested in the negotiating documents and work of the Uruguay Round, and presumably will be a trend that will continue. 
Although the policy goals of permitting preferential systems originally may have been those expressed above, as decades passed it became clear that other objectives played a very prominent role in the desire of certain countries to develop preferential trading bloc systems. In particular, the uses or, some would say, misuses of the 'unfair trade rules', such as anti-dumping or countervailing duties, have led some countries to seek some relief from the harsh application of those duties, particularly from the United States. Thus, Canada approached the United States for the development of a free trade system, with one of its most important objectives being to ameliorate the hazards of the US unfair trade laws (see Bello and Holmer, 1990; and McKinney, 1991). Similar motivations can be detected in the Mexican request to the US for a preferential trading bloc. ${ }^{6}$

In addition, countries have become more frustrated with GATT. The large numbers and wide diversity of economic and trading systems represented, coupled with a 'lowest common denominator' approach partially encouraged by the MFN clause, have made it sometimes difficult to achieve progress within the GATT towards resolving some of the issues that world trade developments have posed. This has been particularly true for new areas needing international discipline, such as trade in services or intellectual property. Other issues that have arisen include environmental rules, competition policy, dumping rules and, of course, the ongoing concern about trade in agricultural goods. The GATT dispute settlement system and its institutional structure have been criticised as inadequate for many new developments in world economic relations (Jackson, 1989, Chapter 4). All of these factors have led groups of countries to consider moving beyond the GATT/ multilateral system to develop tighter knit and deeper regulation concerning economic relations for small groups of nations on a preferential basis.

However, these trends are not without dangers. The phrase 'fortress Europe' has been used to express a concern that the European Economic Community will develop as a large tightly-knit bloc, which in many instances will be designed to prevent non-members from trading freely with that bloc. Likewise, other preferential arrangements can be seen to have certain similar characteristics (Davis, 1992) and there is concern that this situation could worsen in the future to the point where a world of three trading blocs might cause rising tensions between them. In the meantime, one can foresee certain tensions among the smaller and varied blocs that are already beginning to develop. Thus, it is argued that it is important that there continue to be a strong multilateral system which can act symbiotically with the preferential systems, so that both can provide benefits to world trade, but avoid some of the dangers or worst features of a bloc system.

\footnotetext{
6 'Mexico Said to Seek Relief from US Dumping and Countervailing Duty Law in FTA Negotiations', International Trade Reporter, Vol. 8, at p. 809 (29 May 1991) (noting that in the early 1980s some 26 per cent of all US trade actions were aimed at Mexico).
} 


\section{THE GATT RULES AND EXPERIENCES}

The GATT rules are primarily expressed in Article XXIV. It is not feasible or appropriate in this short work to try to accomplish a detailed analysis of those rules. Interested readers can look elsewhere for those (Jackson, 1969, Chapter 24; and GATT, 1990). But a few major points should be emphasised.

There are four rules in particular which might be mentioned. These include the 'substantially all' criteria; the 'not on the whole higher' criterion for customs unions; the interim agreement plan and schedule; and the problem of notification and decision of the GATT.

The 'substantially all' criterion is contained in the definition of the entities which are permitted to have the Article XXIV exception. This exception from MFN is granted to customs unions and free trade areas, providing that in each case the participating nations eliminate trade barriers with respect to "substantially all the trade between the constituent territories'. This obviously is at the core of the policy compromise originally contemplated in GATT Article XXIV, whereby the advantages of a preferential agreement that went so far as to eliminate substantially all the barriers, would be deemed to outweigh the disadvantages of departure from MFN. Nevertheless, the phrase 'substantially all' is troublesomely ambiguous. Likewise, the word 'eliminate' poses problems.

For customs unions (which not only eliminate barriers between the members, but form a common external trade regulation system regarding imports from third countries) there is the additional requirement that the regulations and duties of the common external system shall 'not on the whole be higher or more restrictive than the general incidence of the duties and regulations' applicable prior to the formation of the union. This language also has been troublesome. On the one hand, it is argued that essentially the new union need only 'net out' the various advantages and disadvantages granted to third country trade to fulfil this requirement. On the other hand, there have been troublesome issues of negotiating the changes in external duties, particularly when they involve pre-existing 'bindings' by certain countries that became members of the broader preferential area (GATT, 1988; and International Trade Reporter, 1987).

The Article XXIV privilege of MFN exception applies not only to free trade areas or customs unions, but also to a third category known as an 'interim agreement', designed to lead to the formation of a customs union or free trade area. This GATT provision pragmatically recognises that a customs union or free trade area cannot come into being overnight. There needs to be a period of adjustment and transition. Thus, the GATT language about an interim agreement states that it shall 'include a plan and schedule for the formation of such customs union or of such a free trade area within a reasonable length of time'. Once again, this language has been troublesome, particularly the question of what is a 'reasonable length of time' (see GATT, 1972a, 1972b and 1976). 
Finally, GATT Article XXIV provides some procedural rules regarding new preferential arrangements, requiring that they be notified to the Contracting Parties. Likewise, the language of Article XXIV (paragraph 7) states that if, after studying the notification, the Contracting Parties find that an appropriate agreement is not likely to result within a period that is reasonable, the Contracting Parties shall make recommendations and the preference parties shall not maintain or put into force their agreement if they are not prepared to modify it in accordance with those recommendations. The interesting thing about this procedural language is that it does not require advance or later approval of the Contracting Parties of GATT. Instead, it places the initiative with the Contracting Parties to put forward recommendations for changes in the preferential agreement. This means that technically, once the agreement has been notified to the GATT, unless the Contracting Parties can somehow arrive at an agreed set of recommendations, the language of GATT permits the preference parties to go ahead. The presumption is thus in favour of the preferential arrangement. To the knowledge of this author, the Contracting Parties of GATT have never made an agreed set of recommendations to notifiers of preferential agreements. Thus, many such arrangements have been entered into and operated which arguably do not fully comply with the policy goals and the intent and spirit of Article XXIV of GATT (see Dam, 1963; GATT, 1988; and International Trade Reporter, 1987).

Furthermore, in applying Article XXIV over some decades, it has become increasingly clear that the language of Article XXIV is not adequate for the developing international economic practices today. For example, neither the GATT generally, nor the language of Article XXIV, deal with the important question of 'rules of origin' by which preferential parties determine whether goods are entitled to receive the preference of their arrangement. Rules of origin can be very damaging to the trade of third parties if the rules are designed to strongly favour products and parts manufactured within the preferential area (see Vermulst, Bourgeois and Waer, forthcoming; and Jackson, 1989, Chapter 4). Likewise, certain other trade policy laws and rules are not clearly addressed in the GATT language. For example, how does a safeguard or escape clause measure operate? Can a preferential arrangement give preferences to its preference parties in the application of an escape clause? Arguably, the answer should be yes, since the preferential group should be treated more like a single trading entity. A similar argument or problem is raised by the unfair trade rules (anti-dumping and countervailing duties), but there is now a practice of tolerating preferential agreements which do not eliminate such unfair trade rules between the preference parties. ${ }^{7}$

\footnotetext{
${ }^{7}$ See US-Canada Free Trade Agreement, 22 December 1987-2 January 1988, Article 1902, H.R. Doc. No. 216, 100th Cong., 2d Sess. 297 (entered into force 1 January 1989), reprinted in International Legal Material, Vol. 27, at p. 281 (1988); GATT FTA Report; Jackson (1983 and 1989). Note, however, that the agreement also contemplates the two countries negotiating a substitute system of rules in both countries for anti-dumping and countervailing duties as applied to their bilateral trade. See US-Canada Free Trade Agreement, Articles 1906-1907.
} 
Furthermore, there are a number of issues regarding the institutional structure of preferential arrangements, particularly those relating to dispute settlement. Since one of the motivations for preferential arrangements is a certain frustration with the GATT, it is not surprising to find different procedures in some arrangements. This might detract from the eligibility of such a system for the GATT Article XXIV exception.

Another area of considerable ambiguity, even with regard to the traditional subjects of the GATT, includes the application of certain other GATT exceptions, such as the general exceptions of Article XX (e.g. health regulations and competition) and the newly prominent issues of environmental regulation. The major new subjects of trade in services and intellectual property can also be a question, at least for future development of standards and policies relating to preferential areas. $^{8}$

Indeed, there are so many variations and so many possible preferential arrangements, that nations entering them may find it necessary to develop a new type of 'MFN' clause: a clause which will ensure to the preference parties, preferences at least as favourable as those granted to other potential preferential parties when a nation belonging to one, enters into additional similar arrangements!

The GATT experience is extensive. In a list developed by the GATT Secretariat, there are almost 80 preferential arrangements which have been notified to the GATT or otherwise have GATT implications. In many cases, there have been doubts raised as to whether some of these arrangements comply with the criteria established by Article XXIV of GATT. Yet there has not yet been a concrete 'turn down' by the GATT system. All this has led to discussion about the need to revise the GATT, or to establish more detailed interpretations for Article XXIV, discussion which has been resisted by some prominent trading countries in the GATT. ${ }^{9}$

\section{NEW SUBJECTS AND THE CHANGING WORLD: BEYOND ARTICLE XXIV}

As indicated in Section 2, the reasons today why various countries wish to enter into preferential trade and economic groupings go well beyond the rationale originally conceived in the GATT of the 1940s. During the course of the decades of GATT's experience, statesmen and political leaders have learned that a number of problems are affecting trade relations that were either not conceived at all, or hardly conceived, in the GATT. Prime examples include trade in services and intellectual property. In general, the focus has shifted from tariffs to non-tariff barriers and the latter are myriad in number. As the bilateral discussions between

\footnotetext{
${ }^{8}$ See, e.g., 'Conference Explores Issues, Obstacles and Support for NAFTA Agreement', IMF Survey, 3 August 1992, at p. 242; Round Table Discussion, supra note 4. See also note 12, infra. 9 -Understanding on the Interpretation of Article XXIV of the General Agreement on Tariffs and Trade', Dunkel Draft, supra note 2, at pp. U1-4. See also US-Israel Free Trade Agreement, 2 April 1985, TIAS, reprinted in International Legal Materials, Vol. 24, at p. 653 (1985).
} 
the United States and Japan, entitled 'SII - Structural Impediments Initiative', demonstrate, ${ }^{10}$ trade relations now require consideration of matters formally thought to be well within national sovereignty and matters which are deeply embedded in societal structures and cultures. Thus, when small groups of nations decide to join together in a preferential system, there is the possibility (and indeed demonstrated temptation) for such groups to develop preferences which are effectuated through matters that not only are not mentioned by Article XXIV of GATT, but often not mentioned at all in the GATT. These might include a number of different kinds of regulatory standards which would address environmental concerns or prudential concerns in the area of financial services, or labour standards, or even human rights. One can foresee some preferential areas developing environmental rules that give advantages to the preference partners, while disadvantaging trade from third countries. The same might be true for a number of other subjects.

In some cases, these matters are dealt with in so-called 'transition' or 'phase in' rules. Obviously, movements towards freer trade tend to require adjustment in the preference participants' societies, and there is often a desire to limit the scope of that adjustment by using transition rules that exclude advantages to trade from the third countries. In many cases, the treaty draftsmen are in uncharted waters, and the GATT does not provide an adequate discipline to prevent the preferential arrangement from undermining trade goals of the broader multilateral system in a way that was not contemplated in the language of Article XXIV.

Another dimension of these new issues is the questions about the impact of the preference system arrangement itself on a number of non-economic aspects of the countries concerned. Thus, there is developing evidence and opinions that preferential arrangements can have a number of effects in the societies concerned, such as altering government structures, changing cultures, requiring new standards of governmental regulation (such as environmental and labour standards), etc. (see Adams, 1992; and Belmont Policy Centre, 1991 and 1992). In addition, participants in the preferential arrangement may want to explicitly or implicitly use the advantages of the preference system to induce certain kinds of non-economic action on the part of participants or proposed new members. For example, the existing participants may require new entrants to develop stronger protection of human rights as a condition of such entry (see Brown, 1992a and 1992b).

\section{THE WESTERN HEMISPHERE AND ITS POSSIBILITIES}

One of the most intriguing possibilities for a new preferential arrangement is that which has been mentioned for the Western Hemisphere. Approximately a

\footnotetext{
${ }^{10}$ US Trade Representatives' Office, Joint Report of the US-Japan Working Group on the Structural Impediments Initiative (28 June 1990); Japan Federation of Economic Organisations, Interim Report on the Future of Japan-US Economic Relations and the Structural Impediments Initiative, reprinted in Inside US Trade, 'Special Report', 26 June 1992, at S5.
} 
decade ago, the United States (after developing a preference on auto products with Canada and a more general programme for the Caribbean) began to entertain petitions to enter into free trade areas. Israel was first ${ }^{11}$ and then came Canada. ${ }^{12}$ After that, Mexico requested a similar arrangement and, after an extraordinarily detailed negotiation, we now have a draft 'NAFTA' (North American Free Trade Area). ${ }^{13}$ There has been a great deal of speculation about whether the NAFTA would be broadened, accepting other members from the Western Hemisphere, and indeed participants have mentioned this possibility. Thus there are those who contemplate that, during the course of some years, possibly the remainder of this decade, there could develop a free trade area consisting of most or all of the countries in this hemisphere (Zoellick, 1991; and The Economist, 1992). Already, experience in the case of Canada and the anticipation of the NAFTA suggests that a broader Western Hemisphere arrangement could have staggering implications, mostly beneficial for the citizens of this hemisphere. Several points should be made.

First, it is reasonably clear, as suggested above, that although there is a very strong economic policy motivation for the development of a broader hemisphere FTA, there are a number of non-economic policy objectives implicit or explicit in such an arrangement. This includes democratisation, demilitarisation, respect for human rights, development of environmental rules, amelioration of certain worker migration problems, etc. These are linked to the more explicit goals of a potential FTA to enhance world welfare through advantages of economies of scale and comparative advantage, and to enhance investment flows, protection of property rights, etc.

Second, just as there is talk about a 'fortress Europe', there are grounds to be concerned about similar tendency in a Western Hemisphere FTA, a 'fortress America'. Thus, the question of a broader multilateral discipline for trading blocs, to keep them from fighting amongst themselves, is raised.

\section{RECONCILING COMPETING OBJECTIVES: DIRECTIONS OF POTENTIAL MULTILATERAL SUPERVISION}

All these factors make it reasonably clear that the GATT and its Article XXIV, as well as the more ambiguous legal framework of the 1979 enabling clause, are woefully inadequate for the tasks required of a multilateral system to provide some sort of adequate supervision and discipline on certain of the more dangerous

"See US-Israel Free Trade Agreement, supra note 9.

${ }^{12}$ See US-Canada Free Trade Agreement, supra note 7.

${ }^{13}$ Draft NAFTA texts on investment, rules of origin, agriculture and textiles (21 February 1992), reprinted in Inside US Trade, 'Special Report', 27 March 1992; Draft NAFTA texts on intellectual property rights, financial services and land transportation (21 February 1992), reprinted in Inside US Trade, 'Special Report', 24 March 1992. See also Golden (1992a and 1992b) and Jackson (1989. Chapter 4). 
tendencies of trading blocs. GATT Article XXIV is out of date, and some would say fatally flawed from the outset (given its inability to impose some GATT discipline). This raises the question of what needs to be done in the future. The Dunkel Draft (December $1991 \mathrm{draft}$ agreements in the context of the Uruguay Round) ${ }^{14}$ includes a draft 'Understanding on the Interpretation of Article XXIV', which establishes some useful principles and benchmarks for providing rigour to the language of Article XXIV. For example, a 'reasonable length of time' is said not to exceed 10 years, except in exceptional cases. This draft agreement would undoubtedly be useful if adopted, and one can hope that it will become part of the Uruguay Round package. But it is also clear that it leaves much open. The draft agreement on services also has a clause concerning 'economic integration' or preferential agreements. ${ }^{15}$ It is very important that services trade be brought under this type of discipline, and the draft Article $\mathrm{V}$ of the services Dunkel draft text is a valuable start. Nevertheless, more will be needed. Some subjects for consideration in this regard might include:

1. Strengthened GATT/MTO review of new agreements, with strong emphasis on transparency. In.many ways, the preferential agreements are justified (even in some cases when they do not meet the Article XXIV criteria). They provide an outlet for smaller groups of countries to go well beyond what the GATT seems able to design in the way of rules and disciplines for international trade relations, and this is often commendable. Likewise, they provide an opportunity for experimentation with various rules which can then later be assimilated into the broader multilateral system. But it can be argued that a more detailed report should be presented to the GATT and available to all Contracting Parties, and opportunity to comment (and in some cases, depending on specific rules such as those in the Dunkel text, to impose a requirement of change) be made available.

2. Regular periodic reviews should be strengthened. Periodic reviews of preferential trade blocs could be developed along the lines of the new TPRM (Trade Policy Review Mechanism) of the GATT.

3. GATT dispute settlement provisions should be available, as suggested by the Dunkel draft, to challenge 'nullification or impairment' imposed on third parties by preference arrangements.

4. There should be an opportunity to develop some specific rules which would obligate the preference partners and the preference arrangement institutions, so as to provide the basis of a complaint under dispute settlement processes. These rules might require, for example, regulatory actions to be the 'least trade restrictive' possible. The rules of origin provisions in the GATT Dunkel draft text ${ }^{16}$ are also highly relevant and could be extremely important.

\footnotetext{
${ }^{14}$ See supra note 9.

is 'Agreement on Trade in Services', Article V, Dunkel Draft, supra note 2, at Annex II, pp. 9-11.

16 'Agreement on Rules of Origin', Dunkel Draft, supra note 2, at pp. D1-4.
} 


\section{REFERENCES}

Adams, W.J. (ed.) (1992), Singular Europe: Economic and Polity of the European Community After 1992 (University of Michigan Press).

Bello, J.H. and H.E. Moyer (1990), A Guide to the US-Canada Free Trade Agreement, 816-17.

Belmont Policy Centre (1991 and 1992), The New Treaty on European Union, 1 and 2.

Bradsher, K. (1992), 'Negotiators Hope to Finish Free Trade Pact Today', New York Times, (6 August), $\mathrm{C} 1$.

Brown, J.M. (1992a), 'Threat to Turkish EC Deal', Financial Times (7 July), 3.

Brown, J.M. (1992b), Financial Times (10 July), 6.

Dam. K. (1963), 'Regional Economic Arrangements and the GATT: The Legacy of Misconception', University of Chicago Law Review, 30, 615.

Davis, B. (1992), 'Pending Trade Pact with Mexico, Canada has a Protectionist Air', Wall Street Journal (22 July), 1 and 7.

D'Oppuers, S. (1987), 'The ECD, WEU, Messina, Val Duchesse, Rome', in Europe, Dream, Adventure, Reality, 105-27.

Fontaine, F. (1987), 'The Schuman Plan and the ECSC'.

GATT (1972a), 'Working Party Report-EEC Agreement of Association with Malta', Basic Instruments and Selected Documents, 19th Supp. (adopted 29 May), 92-3.

GATT (1972b), 'Working Party Report-EEC Agreement of Association with Turkey', Basic Instruments and Selected Documents, 19th Supp. (adopted 25 October), 102-105.

GATT (1976), 'Working Party Report-Agreement Between European Community and Israel'. 23rd Supp. (adopted 15 July), 63.

GATT (1980), Basic Instruments and Selected Documents, 26th Supp. (March), 203.

GATT (1988), 'Working Party Report Accession of Portugal and Spain to the European Community', GATT doc. L/6405, Basic Instruments and Selected Documents, 35th Supp. (adopted 19-20 October), 300-301.

GATT (1990), Analytical Index.

GATT (1991), 'Working Party Report-US-Canada Free Trade Agreement', GATT doc. L/6927 (12 November), reprinted in Inside US Trade, 'Special Report' (29 November), S2.

Golden, T. (1992a), 'Talks Resume to Complete North American Free Trade Pact', New York Times (26 July), 8.

Golden, T. (1992b), 'Progress But No Agreements in Trade Talks', New York Times (27 July), C1.

Hurrell, A. (1992), 'Latin America in the New World Order: A Regional Bloc of the Americas', International Affairs, 68, 131 and 134.

International Trade Reporter (1987), 'European Community Foreign Ministers Sign Agreement Settling Trade Dispute, Averting Higher US Tariffs' (4 February), 122.

Jackson, J.H. (1969), World Trade and the Law of GATT (Bobbs-Merrill Co.), 580.

Jackson, J.H. (1983), 'Equality and Discrimination in International Economic Law: The General Agreement on Tariffs and Trade', The British Yearbook of World Affairs, 224.

Jackson, J.H. (1989), The World Trading System: Law and Policy of International Relations (Cambridge, MA: The MIT Press).

Jackson, J.H. (1992), 'GATT and the Future of International Trade Institutions', Brooklyn Journal of International Law, 18, 25-6.

Jackson, J.H. (1993), 'The European Communities and World Trade: The Commercial Policy Dimension', in W.J. Adams (ed.), Singular Europe: Economy and Polity of the European Community Afier 1992 (University of Michigan Press).

McKinney, J. (1991), 'Dispute Settlement Under the US-Canada Free Trade Agreement . Journal of World Trade, 25, 118-20.

Morici, P. (1992), Foreign Affairs, 87 (Summer), 101.

Smith, P. (1992), 'The Political Impact of Free Trade on Mexico', Journal of Inter-American Studies and World Affairs.

The Economist (1992), 'Free-Trade Free-For-All' (4 January), 63.

Vermulst, E.A., J. Bourgeois and P. Waer (forthcoming), Rules of Origin (University of Michigan Press). 